Masthead Logo

Wayne State University

Law Faculty Research Publications

Law School

$1-1-2001$

\title{
Making the Familiar Conventional again
}

Steven L. Winter

Wayne State University

\section{Recommended Citation}

Steven L. Winter, Making the Familiar Conventional again, 99 Mich. L. Rev. 1607, 1636 (2001)

Available at: https://digitalcommons.wayne.edu/lawfrp/381

This Article is brought to you for free and open access by the Law School at DigitalCommons@WayneState. It has been accepted for inclusion in Law Faculty Research Publications by an authorized administrator of DigitalCommons@WayneState. 


\title{
MAKING THE FAMILIAR CONVENTIONAL AGAIN
}

\author{
Steven L. Winter*
}

Minding The LAw. By Anthony G. Amsterdam and Jerome Bruner. Cambridge: Harvard University Press. 2000. Pp. 448. \$35.

In 1984, Gerald López published his groundbreaking and still remarkable Lay Lawyering, ${ }^{1}$ employing then-recent developments in cognitive science to reexamine and reconfigure basic questions of law and legal reasoning. Three years later, Charles Lawrence's The Id, the Ego, and Equal Protection: Reckoning with Unconscious Racism ${ }^{2}$ used insights from cognitive and Freudian psychology to probe the problem of racism and the inadequacy of the law's response. George Lakoff's Women, Fire, and Dangerous Things appeared that same year. ${ }^{3}$ It was followed by a series of articles in which I examined a range of legal and theoretical issues in light of the new learning about categorization and human reasoning. ${ }^{4}$ Nineteen ninety-three saw the publication of

* Professor of Law, Brooklyn Law School. B.A. 1974, Yeshiva University; J.D. 1977, Columbia University School of Law. Professor Winter is the author of $A$ Clearing in the Forest: Law, Life, and Mind from the University of Chicago Press, available November 2001. -Ed.

I am grateful to Emilio Boehringer for his research assistance and to Lynn Winter, Mark Johnson, Gary Minda, Jeremy Paul, and Dick Posner for their sound advice and stalwart support. This work was supported by a summer research grant from the Brooklyn Law School.

1. 32 UCLA L. REV. 1 (1984). Other early applications of cognitive science are John D. Ayer, Isn't There Enough Reality to Go Around? An Essay on the Unspoken Promises of Our Law, 53 N.Y.U. L. REV. 475 (1978), and John L. Barkai, A New Model for Legal Communication: Sensory Experience and Representational Systems, 29 CLEV. ST. L. REV. 575 (1980).

2. 39 STAN. L. REV. 317 (1987).

3. George LaKoff, Women, Fire, and Dangerous Things: What Categories REVEAL ABOUT THE MIND (1987). That same year also saw the publication of Mark Johnson's important companion volume. MARK JOHNSON, THE BODY IN THE MIND: THE BODILY BASIS OF MEANING, IMAGINATION, AND REASON (1987).

4. See, e.g., Steven L. Winter, The Metaphor of Standing and the Problem of SelfGovernance, 40 STAN. L. REV. 1371 (1988) [hereinafter Winter, Metaphor of Standing]; Steven L. Winter, Transcendental Nonsense, Metaphoric Reasoning, and the Cognitive Stakes for Law, 137 U. PA. L. REV. 1105 (1989) [hereinafter Winter, Transcendental Nonsense]; Steven L. Winter, The Cognitive Dimension of the Agon Between Legal Power and Narrative Meaning, 87 MICH. L. REV. 2225 (1989) [hereinafter Winter, Narrative Meaning]; Steven L. Winter, Bull Durham and the Uses of Theory, 42 STAN. L. REV. 635 (1990); Steven L. Winter, An Upside/Down View of the Countermajoritarian Difficulty, 69 TEXAS L. REV. 1881 (1991) [hereinafter Winter, Upside/Down View]; Steven L. Winter, Death Is the Mother of Metaphor, 105 HARV. L. REV. 745 (1992) (review essay); Steven L. Winter, The Meaning 
articles by my colleagues Gary Minda and Donald Jones on, respectively, cognitive theory and the law of boycotts and the linguistic and metaphorical construction of race. ${ }^{5}$ Two years later, Gary L. Blasi's What Lawyers Know: Lawyering Expertise, Cognitive Science, and the Functions of Theory ${ }^{6}$ and Linda Hamilton Krieger's The Content of Our Categories: A Cognitive Bias Approach to Discrimination and Equal Employment Opportunity ${ }^{7}$ both appeared. More recently, Larry Solan has reexamined issues of statutory construction and criminal law in light of what cognitive science has revealed about how humans actually categorize and reason. ${ }^{8}$

For all that, cognitive studies of law remain marginal in the academy. So, for those toiling in the field, the arrival of Anthony Amsterdam ${ }^{9}$ and Jerome Bruner' ${ }^{10}$ Minding the Law is an occasion of some moment. After all, when two such éminences grises turn their considerable intellectual talents to a burgeoning if still nascent subject, one has reason to expect the kind of epochal statement that can galvanize or reformulate a field. Jerome Bruner is a titan of cognitive and cultural psychology, the author of several books and numerous articles

of “Under Color of" Law, 91 MiCH. L. REV. 323 (1992) [hereinafter Winter, "Under Color of" Law]; Steven L. Winter, The Constitution of Conscience, 72 TEX. L. REV. 1805 (1994). Two other articles from the same period are Jay Feinman's The Jurisprudence of Classification, 41 STAN. L. REV. 661 (1989) and Albert J. Moore's Trial by Schema: Cognitive Filters in the Courtroom, 37 UCLA L. REV. 273 (1989).

5. Gary Minda, The Law and Metaphor of Boycott, 41 BuFF. L. REV. 807 (1993); D. Marvin Jones, Darkness Made Visible: Law, Metaphor, and the Racial Self, 82 GEO. L.J. 437 (1993). Minda has further developed these ideas in a fine book. GARY MINDA, BOYCOTT IN AMERICA: HOW IMAGINATION AND IDEOLOGY SHAPE THE LEGAL MIND (1999).

6. 45 J. LEGAL EDUC. 313 (1995); see also Brook K. Baker, Beyond MacCrate: The Role of Context, Experience, Theory, and Reflection in Ecological Learning, 36 ARIZ. L. REV. 287 (1994); Gary L. Blasi, What's a Theory For?: Notes on Reconstructing Poverty Law Scholarship, 48 U. Miami L. REv. 1063 (1996); John Martinez, A Cognitive Science Approach to Teaching Property Rights in Body Parts, 42 J. LEGAL EDUC. 290 (1992).

7. 47 STAN. L. REV. 1161 (1995); see also Linda Hamilton Krieger, Civil Rights Perestroika: Intergroup Relations After Affirmative Action, 86 CAL. L. REV. 1251 (1998).

8. Lawrence M. Solan, Law, Language, and Lenity, 40 WM. \& MARY L. REV. 57 (1998); Lawrence M. Solan, Learning Our Limits: The Decline of Textualism in Statutory Cases, 1997 WIS. L. REV. 235; Lawrence M. Solan, Refocusing the Burden of Proof in Criminal Cases: Some Doubt About Reasonable Doubt, 78 TEXAS L. REV. 105 (1999); see also LAWRENCE M. SOlAN, THE LANGUAGE OF JUDGES (1993). For other recent work applying cognitive theory to law, see Gregory S. Alexander, A Cognitive Theory of Fiduciary Relationships, 85 CoRnell L. REV. 767 (2000); Carl S. Bjerre, Secured Transactions Inside Out: Negative Pledge Covenants, Property and Perfection, 84 CoRnell L. REV. 305 (1999); Stuart P. Green, Prototype Theory and the Classification of Offenses in a Revised Model Penal Code: A General Approach to the Special Part, 4 BuFf. CRIM. L. REV. 301 (2000); and Patrick J. Ryan, A Mental Model of Civil Procedure 28 RUTGERS L.J. 637 (1997).

9. Judge Edward Weinfeld Professor of Law, New York University School of Law.

10. Research Professor of Psychology, Senior Research Fellow, New York University School of Law. 
on education, mind, and culture. ${ }^{11}$ Tony Amsterdam is a legendary figure both in the profession and in the academy. One of the country's leading litigators, his work with the NAACP Legal Defense Fund includes such landmark cases as Furman v. Georgia ${ }^{12}$ and Lockett $v$. Ohio. ${ }^{13} \mathrm{He}$ is also a pioneer of clinical legal education and the author of the classic article on the Fourth Amendment. ${ }^{14}$ Add to this an already vibrant literature on which to build, and it should be easy to see why expectations might run high. The combined expertise and experience of two distinguished lifetimes should lead to the kind of magisterial work that plumbs the fundamental questions of the discipline or marks out bold new directions for research and writing.

By this standard, the book is something of a disappointment. Not that it doesn't have its moments. The chapter on categorization provides a panoramic view of recent developments in the field that should serve as an able introduction for those not versed in this material. Chapter Three's discussion and redescription of Justice Scalia's plurality opinion in Michael $H$. v. Gerald $D .{ }^{15}$ as instantiating classic Western adultery myths is a standout. Chapter Nine's summation and indictment of the way in which America's egalitarian promise has repeatedly been smashed on the cruel anvil of race is an effective, often moving jeremiad. And the book does a real service in drawing attention to an important, too-often neglected area of study.

That alone is an invaluable contribution. Indeed, the authors characterize their book as a "propaedeutic," or introduction, to a more productive theoretical study of law (p. 289). Still, for all its obvious promise, the book never seems to transcend a garden-variety legal realism: "Our aim," the authors proclaim, "is to intensify awareness of the decisions and choices constantly being made by the people who make the law - and of the cognitive devices that those people are

11. See, e.g., JEROME BRUNer, ACTS OF MEANING (1990) [hereinafter BRUNER, ACTS of Meaning]; Jerome Bruner, ACtual Minds, Possible Worlds (1986); Jerome BRUNER, THE CULTURE OF EDUCATION (1996); JEROME S. BRUNER, ON KNOWING: ESSAYS FOR THE LEFT HAND (1979); JEROME S. BRUNER, THE PROCESS OF EDUCATION (1960); JEROME S. BRUNER, TOWARD A THEORY OF INSTRUCTION (1966); JEROME S. BRUNER, J.J. GOODNOW, \& G. A. AUSTIN, A STUDY OF THINKING (1956).

12. 408 U.S. 238 (1972).

13. 438 U.S. 586 (1978). Amsterdam also appeared before the Supreme Court in Pulley v. Harris, 465 U.S. 37 (1984); Jurek v. Texas, 428 U.S. 262 (1976); Woodson v. North Carolina, 428 U.S. 280 (1976); Roberts v. Louisiana, 428 U.S. 325 (1976); Branzburg v. Hayes, 408 U.S. 665 (1972) (arguing No. 70-57, United States v. Caldwell); Maxwell v. Bishop, 398 U.S. 262 (1970); Bachellar v. Maryland, 397 U.S. 564 (1970); and Georgia v. Rachel, 384 U.S. 780 (1966) (civil rights removal). During this same period, he participated in other civil rights and death penalty cases far too numerous to mention.

14. Anthony G. Amsterdam, Perspectives on the Fourth Amendment, 58 MiNN. L. REv. 349 (1974). Until the recent change in the Bluebook, his student note was the only studentauthored article conventionally cited by author. Anthony G. Amsterdam, Note, The Voidfor-Vagueness Doctrine in the Supreme Court, 109 U. PA. L. REV. 67 (1960).

15. 491 U.S. 110 (1989). 
forever using to conceal their choices and avoid responsibility for their decisions" (p. 247). In the end, the book provides only the most etiolated accounts of mind as unsituated subjectivity and of law as nothing but the product of rhetorical manipulation. I take up the question of why in Part I of this Review. The answer, I think, is instructive: it says something not only about the current state of legal theory, but also more broadly about scholarship as an inherently communal enterprise. The succeeding sections defend these claims in more particular contexts: Part II focuses on the discussions of categorization, rhetoric, and Justice Powell's majority opinion in McCleskey v. Kemp ${ }^{16}$; Part III focuses on the book's claims with respect to narrative and Justice Scalia's plurality opinion in Michael H.; and Part IV offers, by way of conclusion, an alternative prolegomenon to the study of law and mind that focuses on what I believe to be the larger political and socialtheoretical stakes.

\section{SANTAYANA'S FIRST COROLLARY}

At this stage of the game, a book on cognitive theory and law should take up the big questions. One reason the book disappoints is that it fails to face up to the issues raised by the material with which it deals. It notes that "[h]ow the category game is played is among the founding quandaries of philosophy of mind" (p. 26), but it explicitly declines to commit itself to a particular view of categorization (pp. 26$27,29,37-42$ ). Though it recognizes that the questions of how category prototypes are formed and how similarity within a category is judged are "of interest in trying to understand how legal categories come into being and are used" (p. 41), it never returns to those issues. So, too, the book never grapples with the question of the nature of law - i.e., what law is and how it is supposed to operate. It raises but, in the end, finesses the question of "how cultural predilections find their way into the adjudicative process" (p. 77). Perhaps most glaringly, it concludes with the observation that law "is driven neither by immutable truths engraved in a fixed body of rules, nor by arbitrary whims or vanities" (p. 291), but in fact says very little about what might lie between those widely separated (and hopelessly conventional) poles - providing instead an account that stresses judicial acts of categorization and rhetorical legerdemain.

How could this happen? The explanation, I think, lies in fundamental missteps with respect to organization and standpoint. These two problems are mutually reinforcing; together they determine the warp and woof of the book's peculiar shortcomings.

16. 481 U.S. 279 (1987). 
The organizational problem can be variously characterized, but the heart of it is a striking disjuncture between the insights introduced in the initial chapter on categorization and the subsequent, hands-on analyses of the topics it takes up. The book appears to have been written in alternating chapters on mind and law; each oar laboring quite separately. Perhaps if the "law" chapters had been integrated with the "mind" chapters - so that the discussions of the categorization and rhetorics of particular judicial opinions appeared as illustrations or demonstrations of specific theoretical claims - this would have kept the discussion on its theoretical tracks. But the discrepancies go deeper than the discordance between the discussions of mind and law: because the book never commits itself to a particular theory of mind - too often aspiring to be all things to all people ${ }^{17}$ - it cannot maintain the theoretical consistency a project of this sort demands. Even within the chapters on categorization and narrative, the book often fails to reckon with the epistemological implications of its earlier discussion; indeed, it frequently reverts to exactly those conventional understandings of mind and law that the material on categorization has undermined. In short, the authors fail to heed their own warning that "epistemological issues, with or without ideological dimension, almost always have a consequence for how one goes about one's business."18

The problem of standpoint is twofold. The first is immediately apparent from the introduction's disclaimer (pp. 7-8): the principal legal texts chosen for close reading are decisions of the Supreme Court, mostly on matters of race, with which the authors disagree. (Several, in fact, are cases on which Amsterdam worked or which were litigated by former students.) The authors disclaim any intent to criticize these decisions, though they admit that these particular cases were chosen because their "results struck us as unjust" (p. 7). The actual discussions leave little doubt about the depth of the authors' feelings; as they concede: "our biases will show, sometimes clearly enough" (p. 10).

But this is not a book about the Supreme Court's mishandling of race, or any other legal issue. As the authors note: "To criticize those... results would require normative analyses (including, conspicuously, a statement of our own values and the reasons for them) that constitute a wholly different subject than the subject of this book" (p. 7). This is a book on how the workings of mind affect the doings of law. The decision to study and critique the rhetorical moves of only conservative decisions is, therefore, an odd choice. For one thing, one does not profitably study a phenomenon by observing only those portions of it with which one disagrees and about which one has strong

17. Where else would one find Noam Chomsky, George Lakoff, and Clifford Geertz neatly synopsized and synthesized all within the space of a few pages? Pp. 38-41. (1975).

18. P. 218; cf. Roberto Mangabeira Unger, Knowledge and Politics 1-3 
feelings. For another, this tactic makes it hard for the reader to assess the relevance of cognitive studies to law. The authors acknowledge ( $p$. 8) that the same strategies of narrative and rhetoric are used by Justices of all ideological stripes. Yet, if everyone uses them - indeed, if everyone necessarily uses them because that is how human minds work $^{19}$ - then it is not at all clear how an exposition of those strategies furthers our understanding of law. No one, for example, thinks that the fact that all sides frame their arguments in impeccable English means that a well-done work on English grammar will reveal anything important about law. If the narrative and rhetorical strategies have some valence (whether political or conceptual), if they carry some practical implication for how we might do law differently, then the study of mind and law is of the greatest importance. ${ }^{20}$ But this book leaves us only with the trite admonition that we should be more reflective about our tropes (pp. 8, 297).

Which brings us immediately to the second problem of standpoint. Noting that "lawyers are not the only ones steeped in these processes," the authors declare their "good fortune" that "much insightful study has recently delved these ubiquitous human doings in their general aspects, outside the law" (p. 3; emphasis added). The authors, thus, present themselves as outside experts offering new knowledge to illuminate the law. But, in striking that pose, the authors ignore more than fifteen years of painstaking work within the legal academy applying these insights to law. The dangers of this omission can be serious: as Bruner has elsewhere noted, "the acquisition of knowledge is indeed domain specific and not automatically transferable. ... Each particular way of using intelligence develops an integrity of its own ... that fits it to a particular range of applicability." 21 In the case of legal theory, this omission is particularly deadly because of its ongoing, century-long struggle to escape the remarkably tenacious grasp of the twin ogres of formalism and positivism. ${ }^{22}$ Yet, the singular importance

19. Thus, the authors characterize their book as "about commonplace hidden pitfalls and snares that infest every path that any lawyer or judge could follow," p. 287, and conclude with the observation that, "if we are even close to the mark about how law is interpreted and conducted in real life, it is impossible for lawyers not to be engaged in literary, psychological, cultural, and rhetorical issues. They will be in the thick of them - inevitably." P. 291.

20. See, e.g., Winter, Transcendental Nonsense, supra note 4, at 1113; Steven L. Winter, One Size Fits All, 72 TEx. L. REV. 1857, $1867-68$ (1994). For concrete examples, see Winter, An Upside/Down View, supra note 4; Winter, "Under Color of" Law, supra note 4; and Winter, The Metaphor of Standing, supra note 4. (1991).

21. Jerome Bruner, The Narrative Construction of Reality, 18 CRITICAL INQUIRY 1, 2 (1983).

22. Cf. Roberto Mangabeira Unger, The Critical Studies Movement 1-14 
of recent developments in cognitive theory is that they provide the tools with which to transcend precisely those pitfalls. ${ }^{23}$

In the event, this omission has several negative consequences ranging from the seemingly inconsequential (though really quite substantive) to the obviously profound. Consider at this point three examples. First, Amsterdam and Bruner twice trot out the old saw about the Inuit (the so-called Eskimos) having twenty words for snow (pp. 27,142 ) even though this particular trope was thoroughly discredited more than a decade ago. ${ }^{24}$ English has just as many words for snow e.g., slush, sleet, dusting, flurry, blizzard, avalanche, hardpack, and powder. This may at first blush seem trivial; in fact, it is central to the question of how categories come into being. The reason both we and the Inuit have many words for snow is that linguistic meaning is a pragmatic function that enables us to cope with our environment more effectively - and this is true whether one drives a snowmobile, a dog sled, or a sports utility vehicle. Second, the authors note Berlin and Kay's findings about the regularities in color terms throughout the world's languages and observe that, "Nobody quite understands why this order prevails (p. 21)." Yet, there is a quite detailed neurological account of this phenomenon, as I have previously discussed. ${ }^{25}$ And this, too, matters a great deal because it exemplifies the crucial role of embodiment in cognition, a point we will return to in Part III.

Third, a good part of the book concerns issues of race. Several chapters are devoted to close readings of the Court's opinions in cases such as Prigg v. Pennsylvania, ${ }^{26}$ Plessy v. Ferguson, ${ }^{27}$ McCleskey $v$. Kemp, and Freeman v. Pitts. ${ }^{28}$ Amsterdam and Bruner dissect the ways in which the authors of those opinions use rhetoric and narrative to obscure the baleful effects of official policy on African Americans. "These rhetorical strategies," they explain, "have the effect of allowing the Court to conceal from itself the reality of the choice that it is making" (p. 210). Summarizing their claims, the authors observe that, "We have faulted Justices for ignoring or masking choices that they

23. See, e.g., Winter, Transcendental Nonsense, supra note 4, at 1107-14; Winter, Death Is the Mother of Metaphor, supra note 4, at 746-49, 757-64.

24. See Geoffrey K. Pullum, The Great Eskimo Vocabulary Hoax 166 (1991) ("The prevalence of the great Eskimo snow hoax is testimony to falling standards in academia, but also to a wider tendency ... toward fundamentally anti-intellectual 'gee-whiz' modes of discourse and increasing ignorance of scientific thought."), discussed in Steven L. Winter, Confident, But Still Not Positive, 25 ConN. L. REv. 893, 912-13 (1993).

25. Winter, Transcendental Nonsense, supra note 4, at 1136-41 (discussing BRENT BERliN \& PAUl KAY, BASIC COLOR TERMS: THEIR UNIVERSALITY AND EVOLUTION 7-12 (1969), and Paul Kay \& Chad K. McDaniel, The Linguistic Significance of the Meanings of Basic Color Terms, 54 LANGUAGE 610, 617-26 (1978)).

26. 41 U.S. 539 (1842).

27. 163 U.S. 537 (1896).

28. 503 U.S. 467 (1992). 
put out of play simply by the way they carved their categories, told their stories, or arrayed their words, without acknowledgment of these processes."29 This quite traditional line of argument presupposes that these are deliberate choices, rather than the effects of cultural attitudes and biases deeply inscribed in our categories, our metaphors, and our psyches. That latter point is, of course, the central lesson of Lawrence's, Jones's, and Krieger's important work. But, even on the former, more conventional assumption of choice, it is surprising that the question of what underlies or motivates those choices is never broached. ${ }^{30}$ There is simply no mention of the antecedent work on the cognitive and linguistic aspects of race, let alone any examination of how the phenomena documented by other scholars of mind play out in (or are absent from) these particular decisions. ${ }^{31}$

Omissions of this sort mar the book in fundamental ways. It is not just a matter of the proprieties of scholarship: these omissions detract in material ways from the book's substance. Litigators and students of the federal courts understand the value of the Supreme Court's policy sometimes to delay consideration of a case so that difficult or important issues can be vetted in the lower courts. ${ }^{32}$ Much the same is true with respect to scholarship, where prior discussions help clarify and refine issues, identify flawed arguments and unpromising lines of inquiry, or reformulate old questions in new and more productive ways. A scholar who takes up an area of inquiry without reckoning with the existing literature runs the very serious risk of missing the real issues or, at the least, reinventing the wheel. Thus, we might say that the first

29. P. 287. For a nuanced and sophisticated argument of this sort that probes the ways in which such "choices" are constructed, see MINDA, supra note 5, at 35, 86-98.

30. Consider the following passage from the introduction:

[W] do not intend to portray the Justices as either villains or heroes. Just as our purpose does not extend to criticizing the Justices' results, it does not extend to analyzing their motives. We have neither the information nor the competence to offer assessments in any of the dimensions that distinguish Goodies from Baddies - or to pretend to know what those dimensions might be. [p. 8]

Note the way in which this passage presupposes subjective or individual motive (and the concomitant attribution of fault), but disclaims any and all ability to discern it. Some might think it remarkable that a book on mind and cognition carries no implications for the question of human motivations.

31. Though Cover's work is noted, p. 364 n.3, there is no discussion of his use of the theory of cognitive dissonance to explain the opinions in antebellum decisions such as Prigg. Robert M. COVER, Justice ACCuSEd: ANTISLAVERY AND THE JudiCIAL PROCESS 16674, 240-43 (1975).

32. See Maryland v. Baltimore Radio Show, 338 U.S. 912, 918 (1950) (Frankfurter, J., opinion respecting the denial of certiorari) ("A case may raise an important question but ... [i]t may be desirable to have different aspects of an issue further illumined by the lower courts. Wise adjudication has its own time for ripening."); RICHARD POSNER, THE FEDERAL COURTS: CRISIS AND REFORM 163 (1985); see also Castano v. Am. Tobacco Co., 84 F.3d 734, 748-49 (5th Cir. 1996) (noting that individual lawsuits are superior to class actions for "incipient" or "immature" mass torts because they allow for the exploration and development of difficult issues such as causation). 
corollary of George Santayana's famous dictum is that those who don't contend with the literature are doomed to repeat it. ${ }^{33}$

Unfortunately, this book provides ample evidence of the failure to engage. It is manifest in the way in which the book repeatedly misses the implications of its own discussion of the recent work on categorization and atavistically reproduces the most conventional assumptions about rationality and law. I will examine these phenomena in greater depth and detail in the sections to follow. Consider, for now, two of Amsterdam and Bruner's closing observations. "Results in the law," they tell us,

are achieved by the application of specialized legal reasoning - reasoning within and about doctrinal rules, procedural requirements, constitutional and other jurisprudential theories - and are typically articulated almost wholly in those terms. But final results are underdetermined by such rules, requirements, and theories. [p. 287]

They characterize their contribution thus: "We hope our labors show that decisions which the Justices treated as logically compelled or as grounded in inexorable givens of law and fact were neither" (p. 287). But, surely, we did not need recent developments from the science of the mind just to make points that the legal realists and their successors in the critical legal studies movement have been pressing for a century ${ }^{34}$ When Amsterdam and Bruner say they aim to intensify awareness and expose the cognitive devices by which legal decisionmakers conceal their choices and avoid responsibility (p. 247), it is hard not to hear Felix Cohen's famous admonition of sixty-five years ago:

When the vivid fictions and metaphors of traditional jurisprudence are thought of as reasons for decisions, rather than poetical or mnemonic devices for formulating decisions reached on other grounds, then the author, as well as the reader, of the opinion or argument, is apt to forget the social forces which mold the law. ${ }^{35}$

True, the point probably bears repeating. Nevertheless, I remain confident that the striking advances in cognitive science represent something more than another occasion for the reminder that we should all be more self-aware. ${ }^{36}$ Amsterdam and Bruner set out "to make the

33. See GeORge SANTAYANA, The LIFE Of REASON 284 (1905) ("Those who cannot remember the past are condemned to repeat it.")

34. Even Daniel Williams's otherwise favorable review acknowledges that for "scholars ... this book might have a 'ho hum' quality to it. It is true that much of what one finds in Minding the Law has been circulating within legal academia for nearly two decades." Daniel A. Williams, The Lawyer's Bookshelf: Minding the Law, N.Y.L.J., Dec. 5, 2000, at 2. Williams, however, ignores the foundational contributions of the realists, thus understating the point.

35. Felix Cohen, Transcendental Nonsense and the Functional Approach, 35 CoLUM. L. REV. 809, 812 (1935).

36. How much more - and the relationship between these developments and the most sophisticated of the legal realist insights — is the subject of my forthcoming book, STEVEN L. 
familiar strange again" (pp. 1, 134, 286). In the final analysis, however, they succeed merely in making it conventional all over again.

There is a unifying theme to the problems I have canvassed under the rubrics of organization and standpoint. The authors observe that "[i]magination flourishes in aggregation and exchange" (p. 236), but their book is surprisingly monological. It is monological in the way that different portions of the book do not speak to each other. It is monological in its refusal to engage in dialogue on the underlying values that plainly motivate its critique of the Supreme Court's decisions on race. And it is monological in not taking more seriously the importance of dialogue with other scholars in defining and extending the horizons of intellectual inquiry.

\section{MisSING THE FOREST FOR THE TREES - MCCLESKEY}

Jerome Bruner is perhaps best known for his social constructivism and his insistence that "culture is constitutive of mind." ${ }^{37}$ But the manner in which the authors connect culture to mind in the current book fails to illuminate the very phenomena they seek to explain. Sometimes, as in the discussion of McCleskey, this failure is quite dramatic.

The opening chapter on categorization starts out promising enough (Chapter Two). Categories, the authors observe, are necessary laborsaving devices that allow us to aggregate experience and treat things in an already familiar way (p. 21). Categories are both adaptive and "pragmatic" - i.e., they are refined or retooled as needed for the tasks at hand. (Remember all the different English words for the category "snow?") "In short, our categories are grounded in conceptions of what matters to ourselves and those on whom we depend - our reference groups ... the people with whom we feel interdependent in the conduct of life" (p. 23). Categories, thus, "promote cohesiveness within cultural groups" and concomitantly exclude or serve to dominate others (p. 34). Consequently, categories can be and sometimes are made the subject of contests for control. But categories generally become entrenched and shape our very perceptions of the world ( $\mathrm{pp}$. 36-37).

The authors note the "newer, more experiential" understanding of categorization "that has challenged the old rationalism" (p. 40). Formal category structures operate in a way that seems virtually independent of context; but, such formal categories "fail (and do not even

WinTER, A Clearing IN THE FOREST: LAW, LIFE, AND MIND (available Nov. 2001). I provide some illustrations in the sections that follow.

37. BRUNER, ACTS OF MEANING, supra note 11, at 33; Bruner, supra note 21 , at 20 ("[T]he human mind cannot express its nascent powers without the enablement of the symbolic systems of culture."). 
try) to map more than a minute and superficial sector of the human scene" (pp. 43-44). The authors underscore the point with the observation that both life and law "are worlds where, as Richard Rorty puts it laconically, ' $n o$ interesting descriptive term has any interesting necessary or sufficient conditions.' " 38 Most of our categories involve "praxic knowledge ... about how the world operates" in the form of scripts ( $p$. 45). This is what Lopez discussed under the rubric of "stock stories" and, following Lakoff, I have discussed under the rubric of "idealized cognitive models. ${ }^{\prime 39}$ Categories formed in this way, as has been explained, ${ }^{40}$ produce a variety of prototype effects. The authors note the earlier (though quickly rejected) assumption that categories formed around prototype experiences, but quite wisely "tend toward the view" that "prototypes ... function tropologically to capture the nature of the system from which a set of categories emerges or is derived" (p. 41).

So far, so good. Some will recognize the congruence between this description and the account of categorization that has been the centerpiece of my work for more than a decade. It should be evident, too, that this understanding of categorization provides an account of culture as the ensemble of knowledge or "know-how" by which people simultaneously negotiate and construct their world. As the authors observe: "If culture is anything, it is a network of models of the world, ways of getting on in it, of tools for thinking and imagining that range from systems of mathematics to genres of storytelling.".41

But problems quickly arise. Despite having noted the challenge posed by the new learning on categorization, the authors instinctively revert to all the assumptions of "the old rationalism."

What are those assumptions? They will seem familiar (if not, indeed, self-evident) because they comprise the Western tradition's core conception of rationality. On those assumptions, reason is understood as hierarchical (i.e., top-down or involving the subsumption of particulars under general rules), definitional (i.e., things are understood

\section{P. 43. Similarly, with respect to speech act theory, the authors note:}

[T] he felicity conditions for various illocutionary acts have turned out to be strongly resistant to any kind of comprehensive or unambiguous codification, except for a few highly ritualized speech acts like christening a ship.... And even for those ritualized acts, the specification of the necessary and sufficient conditions will hold good only within a narrow range of relatively commonplace circumstances.

P. 170.

39. See material cited supra notes $1,3, \& 4$.

40. See, e.g., Winter, Transcendental Nonsense, supra note 4, at 1136-42, 1151-56.

41. P. 39. Cf. Dorothy Holland \& Naomi Quinn, Culture and Cognition, in CULTURAL MODELS IN LANGUAGE AND THOUGHT 4 (D. Holland \& N. Quinn eds., 1987) (viewing culture as "shared knowledge - not a people's customs and artifacts and oral traditions, but what they must know in order to act as they do, make the things they make, and interpret their experience in the distinctive way they do"). 
reductively in terms of the elements that comprise their necessary and sufficient conditions), and characterized by closure (i.e., as in the law of the excluded middle). This view is reflected in the standard form of legal reasoning, which consists in abstracting from an authoritative legal text the principles or criteria that express its necessary and sufficient conditions and, then, deciding the particular case by determining whether it corresponds to those criteria. The "old rationalism" tends heavily toward a binary logic, as in the conventional tautology of formal logic: $P$ or not- $P$. This is reflected as well in a set of traditional dualisms that divide the world into subject and object, mind and body, internal and external, freedom and constraint.

This traditional view is the one actually applied by Amsterdam and Bruner throughout their book. Categories, it turns out, are not built on praxic knowledge; they are top-down. "They are derived," the authors repeatedly assert, "consciously or unconsciously, from some larger-scale theory or narrative about the canonical or desirable state of things in the world." 42 Indeed, they "often get born as empty categories" (p. 39). Categories aren't flexible; they are closed: "We take or make our categories out of ordinary 'logic,' by dint of commonplace rationality that tells us, say, that something can't be $A$ and not- $A$ " (p. 37). Legal reasoning, too, is necessarily hierarchical: "law could not operate without a means of going from its generalities to the particularities of individual cases" (p. 140).

Not only that, but at a surprising number of junctures in the text, categorization turns out to be criterial after all. In the chapter on categorization, the authors maintain that "[c]ategory placement presupposes some process for arriving at a judgment that the pertinent characteristics of the instance you are seeking to place fit the criteria you take to be indicative of category membership." ${ }^{43}$ Consider, as well, two legal examples.

In the discussion of Missouri v. Jenkins, ${ }^{44}$ we are told that Supreme Court Rule 14.1 "intrinsically calls for a definition-matching approach" (p. 67; emphasis added). Exactly why this is so is unclear. The

42. P. 22. This claim is repeated so often that it almost becomes a mantra: "[O]ur categories are derived from more encompassing notions about how the world really is," p. 27; "Our category systems derive from canonical general theories of the world and template narratives about life," p. 28; "We remarked earlier that categories are usually derived or abstracted from either theories or stories," p. 29; "[c]ategories are derived or extracted from larger-scale theories, stories, or normative redes about 'reality,'" p. 37.

43. Pp. 42-43 (emphasis changed from original). But see LAKOFF, supra note 3.

44. 515 U.S. 70 (1995). The question presented in Jenkins was whether, in ordering salary increases, the district court ran afoul of the principle that "a school desegregation remedy ... must directly address and relate to the constitutional violation and be tailored to cure the condition that offends the Constitution ..." Id. at 85 n.3. The argument was that the order was part of an effort to entice white suburban students across district lines by improving the quality of inner-city schools and that, because the lower court had found no interdistrict violation, the salary increase was beyond the court's remedial authority. 
Rule provides that "[o]nly the questions set out in the petition, or fairly included therein, will be considered by the Court." 45 The authors maintain that, "In deciding whether an argument is out of bounds under this rule, the Supreme Court treats ... the Questions Presented as defining a category of potential contentions and asks whether or not each argument advanced by the petitioner falls within the category" (p. 67). But there seems to be no reason why the "fairly included" language should be read so narrowly; moreover, in previous cases the Court had treated an antecedent or logically prior issue as within the scope of the question presented. ${ }^{46}$

In the discussion of Michael $H$., the authors offer only two equally criterial, reductive readings of the cases on the constitutionally protected right to privacy within the family. The authors argue that either we identify the "special quality" that attends relationships within the family and see whether the circumstances of the instant case meet those, or we conclude that what "is special about those relationships must derive exclusively from the pervasiveness, duration, and intensity of the respect they have commanded" (pp. 106-07; emphasis changed from original). The authors fault Justice Scalia for taking the second route and ignoring the first. Yet, they never consider any other mode of extending legal categories - such as, say, Llewellyn's "situationsense ${ }^{\prime 47}$ or one that looks to the needs and mores of contemporary American families.

So, too, Amsterdam and Bruner repeatedly carve the world into what looks suspiciously like the traditional dualism of objectivity and subjectivity. They distinguish between judges who are "relatively category-centered or relatively situation-centered" (p. 108). (But weren't all those praxic understandings situation-centered? Were they not categories?) They distinguish between "the canonical ways laid down by a society's institutional forms" and "the possible worlds generated by the rich imaginations of its members" (p. 15). And they distinguish between rule-application "by deductive, analytic reasoning or by the rules of induction" and what they call "the 'wild card' of all interpretation" (p. 287).

This last point is central to the argument of the book which, as intimated earlier, trades on the conventional idea of subjectivity as es-

45. Sup. Ct. R. 14.1(a).

46. Procunier v. Navarette, 434 U.S. 555, 559 n.6 (1978). In Procunier, the Court granted certiorari on the question whether a claim for negligence states a cause of action under 42 U.S.C. \& 1983; it treated that question as subsuming the question whether the defendants could not be sued because they were entitled to a qualified immunity. There, the Court also noted that its power to decide is not limited by the precise terms of the question. Id. (citing Blonder-Tongue Labs. v. Univ. Found., 402 U.S. 313, 320 n.6 (1971)).

47. Karl N. Llewellyn, The Common law Tradition: Deciding appeals 60-61, $122-23(1961)$. 
sentially autonomous, unconstrained, and originary. ${ }^{48}$ This, after all, is the underlying assumption of the timeworn critique that faults judges for concealing unspoken purposes, values, or beliefs behind the logical or rhetorical facade of their opinions. Thus, it is not surprising that when Amsterdam and Bruner fault various judges for "masking choices that they put out of play simply by the way they carved their categories" (p. 287), what they show us is not how pre-existing social categories import cultural predilections into the law, but rather how judges achieve particular results by manipulating time frames (pp. 72$73,152-53$ ), reifying concepts (pp. 103-05), or manipulating the level of generality at which they state the relevant facts or legal concepts (pp. 67-71, 105-07). These are, of course, familiar modes of critique long since made conventional by scholars associated with critical legal studies. $^{49}$

The assumption of an unconstrained subjectivity appears in more explicit form throughout the book. Notwithstanding the entrenchment of categories "in institutions, in habits of life, in the very language we speak" (p. 36), we are told that, "[c]ategory systems are, in the main, under human control." 50 The authors seek to explain various judicial opinions in terms of canonical narratives of Western adultery myths or of heroes-turned-tyrants, but this explanation breaks down once we are told that the authors of these judicial tales are free to frame the story any way they like. ${ }^{51}$ So, too, autonomous or originary subjectivity determines the shape of reality. Consider these examples:

- "[J]udicial opinions, like other texts, contain the world of which they speak and, by impressing their structure on it, create it in their image." [p. 144]

48. There is, of course, an extensive literature on this phenomenon and its persistence in legal scholarship. See, e.g., Pierre Schlag, The Problem of the Subject, 69 TEX. L. REV. 1627, 1630-31 (1991) ("[I]n their very rhetoric, all these modes of contemporary legal thought establish, depend upon, and eclipse a quintessentially liberal individual subject - what I have elsewhere called the relatively autonomous self...."); Schlag, "Le Hors de Texte, C'est Moi" - The Politics of Form and the Domestication of Deconstruction, 11 CARDOzo L. REV. 1631 (1990); see also Steven L. Winter, Indeterminacy and Incommensurability in Constitutional Law, 78 CAL. L. REV. 1441, 1476-94 (1990).

49. See Mark Kelman, Interpretive Construction in the Substantive Criminal Law, 33 STAN. L. Rev. 591, 593-94 (1.981); Jay Feinman, Promissory Estoppel and Judicial Method, 97 HARV. L. REV. 678, 704-05 (1984); Jennifer Jaff, Frame-Shifting: An Empowering Methodology for Teaching, 36 J. LEGAL EDUC. 249 (1986); Peter Gabel, Reification in Legal Reasoning, 3 RESEARCH L. \& SOC. 27 (1982); Gary Peller, The Metaphysics of American Law, 73 CAlif. L. REV. 1151, 1157-58 (1985); MARK TUSHNET, RED, WHITE AND BluE: A CRITICAL ANALYSIS OF CONSTITUTIONAL LAW 135 (1988); see also LAURENCE TRIBE \& Michael DoRF, ON REAding THE CONSTITUTION 98 (1991).

50. P. 35. To be clear, there is a huge difference between the insight that categories are humanly constructed (in social institutions, forms of life, and language) and the claim that any particular human or group of humans has control over the shape or content of those categories.

51. "What is Trouble and what is Resolution are determined largely by where the teller of the tale chooses to begin it." P. 153. 
- "Western history is a running commentary on the efforts of the powerful to impose a conception of reality of those they would rule." 52

- "Any interpretive construction backed by the power of authority becomes a real social institution." [p. 226]

- "[A]n individual's possible worlds can readily become collective visions (utopian, apocalyptic, redemptive, demonic), later to be institutionalized into possible world communities, local, religious, criminal." [p. 236]

The conventional view of unfettered and unsituated subjectivity achieves an apotheosis of sorts in the discussion of Justice Powell's McCleskey opinion..$^{53}$ Noting Justice Powell's change of heart about his vote in $M c$ Cleskey, the authors offer a close reading of the opinion as "an instructive study of the means by which rhetorics achieve a selfjustification that is strong enough to kill but not strong enough to endure much beyond the killing" (p. 194) and as "a striking symbol of rhetorics' magic" (p. 216). The lesson they would have us draw is that "we end up buying our own rhetorics as avidly as we sell them to others," and they suggest that "[p]erhaps this is why ... judges deciding cases often write exactly like advocates arguing them - even when, as is inherently true in the case of United States Supreme Court Justices, they sit on a court of last resort and need fear no subcelestial reversal" (p. 176). Here, apparently, is a view of subjectivity as so variable, uncertain, inconstant, unstable, and mercurial that it can neither withstand nor stand by the blandishments of its own beguiling rhetoric.

But one doesn't have to look far for a more cogent account, either of the decision or of Powell's subsequent change of heart. Powell tells us in his opinion precisely why he decided as he did; his rather candid self-presentation, moreover, provides a key for unlocking his subsequent change of heart.

The authors devote a fair amount of space to McCleskey (pp. 188$89,194-216)$, but for our purposes the story can easily be telescoped. On the basis of an unusually thorough statistical study by Professor

52. P. 225. A full-fledged discussion of the fatal theoretical flaws in this conventional assertion can be found in Steven L. Winter, The "Power" Thing, 82 VA. L. REV. 721 (1996). I provide a précis below in Part IV. Contrast Bruner's observation in an earlier work that, "For all our power to construct symbolic cultures and to set in place the institutional forces needed for their execution, we do not seem very adept at steering our creations toward the ends we profess ...." BRUNER, ACTS OF MEANING, supra note 11, at 23.

53. Thus, the authors note that Justice Powell "manages with . . . complete consistency to disregard whatever might obstruct his chosen line of march," pp. 202-03; that he and other Justices profess the importance of racial equality "whenever they elect to promote that value," p. 203; and, more implausibly, that he "imbues the words 'indicate' and 'risk' with connotations of conjecture" and "codes the word 'prove' with connotations of actuality," $\mathrm{p}$. 206 (emphasis added). Of course, that is exactly what those words normally connote - as a quick check of your dictionary will confirm. 
David Baldus and his colleagues, ${ }^{54}$ Warren McCleskey challenged the administration of Georgia's capital punishment system. Basically, the Baldus study showed that - controlling for as many as 230 variables - there was a pattern of discrimination based on the race of the victim. White-victim cases, the study showed, were seven times more likely to result in death sentences than black-victim cases; and black defendants who killed white victims were two-and-a-half times more likely to receive the death sentence than were their white counterparts. ${ }^{55}$ The racial disparities were greater still in the "mid-range" cases - that is, cases that were neither among the most aggravated (and, so, likely to receive a death sentence in any case) nor the least aggravated (and, therefore, unlikely to receive a death sentence) ${ }^{56}$ Indeed, the race of the victim was twice as strong a predictor of a death sentence as was the fact that the victim was a police officer (as, in fact, McCleskey's victim was). ${ }^{57}$ Though the district court rejected the study as flawed, both the Court of Appeals and the Supreme Court assumed the study was statistically valid. ${ }^{58}$ The Court ruled, however, that the study did not prove the kind of discrimination prohibited by the Fourteenth Amendment nor the cruel and unusual administration of punishment prohibited by the Eighth.

The authors detail the uses of rhetoric and categorization by which Powell downplays the relevance of these statistics. Many of these critiques are on target. We need consider only two, however, because they simultaneously go to the heart of Powell's opinion and the authors' principal theoretical claim.

Amsterdam and Bruner fault Powell because he stresses "the importance of the criminal justice function that would be jeopardized if McCleskey's claim were recognized," but omits (or "discounts" they use both verbs) "the importance of the values of racial equality that would be jeopardized if McCleskey's claims are not recognized."59 This omission, they conclude, "conspicuously leaves the opinion lacking half the makings of the cost/benefit analysis that Justice Powell is ostensibly conducting" (p. 203).

54. David C. Baldus et al., Equal Justice and the Death Penalty: A Legal AND EMPIRICAL ANALYSIS (1990).

55. Id. at 315 tbl.50. There were very few death sentences in black victim cases, though white defendants were slightly more likely to draw them.

56. Id. at 401-02.

57. Id. at 319-20 tbl.52; id. at 588-89 app.J.

58. McCleskey v. Kemp, 481 U.S. 279, 291 n.7 (1989). They did so, moreover, without reviewing or reversing the trial court's contrary findings of fact. In part, this was because everyone understood that the study was state of the art; in part, it was because the courts wished to foreclose all such challenges to the death penalty.

59. P. 203; see also pp. 188-89. 
The key word here is "ostensible." Perhaps Powell is conducting a sub silentio cost/benefit analysis, but he rather sounds like he is treating the criminal justice system as a value that simply trumps all others:

McCleskey's statistical proffer must be viewed in the context of his challenge. McCleskey challenges decisions at the heart of the State's criminal justice system. "One of society's most basic tasks is that of protecting the lives of its citizens and one of the most basic ways in which it achieves the task is through criminal laws against murder." ... Implementation of these laws necessarily requires discretionary judgments. Because discretion is essential to the criminal justice process, we would demand exceptionally clear proof before we would infer that the discretion has been abused. ${ }^{60}$

The authors note that "the invocation of the lion-hearted "criminal justice system' recurs like a mantra throughout the $M c$ Cleskey opinion" (p. 188). One might take this repetition as a sign of anxiety ${ }^{61}-$ i.e., that Powell feared McCleskey's claims somehow put the system itself at risk:

McCleskey's claim, taken to its logical conclusion, throws into serious question the principles that underlie our entire criminal justice system. The Eighth Amendment is not limited in application to capital punishment, but applies to all penalties. ... Thus, if we accepted McCleskey's claim that racial bias has impermissibly tainted the capital sentencing decision, we could soon be faced with similar claims as to other types of penalty. Moreover, the claim that his sentence rests on the irrelevant factor of race easily could be extended to apply to claims based on unexplained discrepancies that correlate to membership in other minority groups, and even to gender. Similarly, since McCleskey's claim relates to the race of his victim, other claims could apply with equally logical force to statistical disparities that correlate with the race or sex of other actors in the criminal justice system, such as defense attorneys or judges. Also, there is no logical reason that such a claim need be limited to racial or sexual bias. If arbitrary and capricious punishment is the touchstone under the Eighth Amendment, such a claim could - at least in theory - be based upon any arbitrary variable, such as the defendant's facial characteristics, or the physical attractiveness of the defendant or the victim.... ${ }^{62}$

Amsterdam and Bruner criticize the "slippery slope" logic of this passage, arguing (in part) that there are preexisting legal principles with which the Court might have cut off this freefall to absurdity ( $p$. 214-15). This is often true of slippery slope arguments, as critics of the

60. Id. at 297.

61. Cf. COVER, supra note 31 , at $226-56$ (using the theory of cognitive dissonance to explain the belabored formalism in the fugitive slave opinions of Story, Shaw, and other abolitionist judges).

62. McCleskey, 481 U.S. at 314-19 (footnotes and citations omitted). 
genre like to point out. ${ }^{63}$ The problem, however, is that the logic of the first step usually proves corrosive to the ostensible principles that would cabin it.

This is particularly true here, where the logic of the first step is the basic concept of fair and equal treatment. While McCleskey was pending in the lower courts, the Justice Department released a report it had commissioned from the Rand Corporation studying patterns of incarceration in three states over a two-year period. The study showed that whites received shorter prison terms and were paroled sooner than African or Hispanic Americans convicted of the same crimes. ${ }^{64}$ Judge Vance raised the Rand study in a question from the bench during oral argument before the Eleventh Circuit en banc; neither he nor the majority of that court were persuaded by the response that "death is different." ${ }^{65}$ Powell's McCleskey opinion does not cite the Rand study, but it does cite other empirical studies pointing to discrimination in the criminal justice system on the basis of race, gender, and even appearance. ${ }^{66}$

To Justice Brennan, the Court's concern not to "open the door to widespread challenges to all aspects of criminal sentencing" represents "a fear of too much justice." ${ }^{\prime 67}$ And, in my view, Brennan has the better of the argument. But Brennan simultaneously concedes the force of the slippery slope argument: "[S]urely," he continues, "the majority would acknowledge that if striking evidence indicated that other minority groups, or women, or even persons with blond hair, were disproportionately sentenced to death, such a state of affairs would be repugnant to deeply rooted conceptions of fairness." ${ }^{68}$

We don't have to look far to understand why most judges would be reluctant to put the existing system in jeopardy. Here, the authors emphasize the judges' exercise of choice. Elsewhere, Bruner has explained that we do not "shoot our values from the hip, choice-situation

63. See, e.g., Frederick Schauer, Slippery Slopes, 99 HARV. L. REv. 361, 369 (1985) ("Because the slippery slope argument responds to an asserted difference between the instant case and the danger case, the argument presupposes a linguistic description of the instant case that distinguishes it from the danger case."); $i d$. at 382 (arguing that "a slippery slope effect is always in logical and linguistic theory eliminable").

64. White Inmates Freed Earlier, WASH. POST, July 1, 1993, at A13. at $\mathrm{A} 21$.

65. Fay S. Joyce, Hearing Is Urged on Georgia Death Penalty, N.Y. TIMES, Jan. 18, 1984,

66. McCleskey, 481 U.S. at $315-18 \mathrm{nn} .38,40,43$ \& 44 . If discrimination on the basis of appearance still seems a farfetched claim, consider the proposed Santa Cruz ordinance and other material discussed in Robert Post, Prejudicial Appearances: The Logic of American Antidiscrimination Law, 88 CAL. L. REV. 1, 1-8 (2000). See also Note, Facial Discrimination: Extending Handicap Law to Employment Discrimination on the Basis of Physical Appearance, 100 HARV. L. REV. 2035, 2035 (1987).

67. McCleskey, 481 U.S. at 339 (Brennan, J., dissenting).

68. Id. 
by choice-situation. ... Rather, they are communal and consequential in terms of our relations to the cultural community. They fulfill functions for us in that community. ... They become incorporated in one's self identity and, at the same time, they locate one in a culture." The character of the judge is one such culturally-defined identity.

At a later point, the authors read Robert Cover's observation that judicial decisions play out in "a field of pain and death" to say that everything is not, in the end, interpretive (p. 226). But Cover's actual point is that legal interpretation must be understood as part of a social practice of violence. ${ }^{71}$ Cover puts it bluntly, "Judges are people of violence." 72 Because the judge's authority to do violence is always under challenge (if only by McCleskey and his lawyers), the judge must "separate the exercise of violence from his own person. The only way in which the employment of force is not revealed as a naked jurispathic act is through the judge's elaboration of the institutional privilege of force...."73 Contrasting Walker $v$. City of Birmingham ${ }^{74}$ with the Court's refusal to consider constitutional constraints on police violence in cases such as Rizzo v. Goode ${ }^{75}$ and City of Los Angeles $v$. Lyons, ${ }^{76}$ Cover concludes that the judge is " 'strong' when the court is aligned with state violence and 'weak' when the court is a counterweight to that violence. The result in all cases is deference to the authoritarian application of violence, whether it originates in court orders or in systems of administration." 77

If the McCleskey majority prefers order over fairness, it is not because the opinion's "rhetorical strategies have the effect of allowing the Court to conceal from itself the reality of the choice that it is making" (p. 210), but because that is the choice that the Court usually makes. The authors portray the Justices as creatures ensnared by their own rhetoric. But it would be more true to a "cultural psychology"

69. BRUNER, ACTS OF MEANING, supra note 11, at 29.

70. Robert M. Cover, Violence and the Word, 95 YALE L.J. 1601, 1601 (1986).

71. See id. at 1606-07 ("[I]t is precisely this embedding of an understanding of political text in institutional modes of action that distinguishes legal interpretation. . . . Legal interpretation is either played out on the field of pain and death or it is something less (or more) than law."); id. at 1613 ("[L]egal interpretation is as a practice incomplete without violence.").

72. Robert M. Cover, The Supreme Court 1982 Term - Foreword: Nomos and Narrative, 97 HARV. L. REV. 4, 53 (1983).

73. Id. at 54 .

74. 388 U.S. 307 (1967) (holding that an injunction must be obeyed - and violators remain subject to contempt - even when the order is later held unconstitutional).

75. 423 U.S. 362 (1976).

76. 461 U.S. 95 (1983).

77. Cover, supra note 72 , at 56. 
that is concerned "with situated action" within and constrained by a network of roles, relationships, and cultural expectations. Perhaps Powell saw McCleskey differently after four years because he had escaped the magic of his own rhetoric. Or perhaps he saw it differently because, in retirement, he had left behind some of the more straitjacketing constraints of his previous role.

\section{UNITIES OF PLOT, CHARACTER, AND ACTION - MICHAEL $H$.}

In 1989, the Michigan Law Review published an influential symposium on legal storytelling. ${ }^{79}$ My contribution explored the question whether the new learning on categorization could profitably be applied to a topic as nuanced and vast as narrative.$^{80}$ Despite many divergences, we readily recognize Bible stories, Native American and other folktales, modern novels, even avant-garde literature as examples of the single category "narrative." What, I wondered, unites all these very different cultural productions as instances of the same phenomenon?

Much of the literature at that time emphasized the social contingency of narrative, its highly contextual nature, and the degree to which it depends upon subjective processes of interpretation. Consider, for example, Bruner's roughly contemporaneous 1991 effort "to lay out the ground plan of narrative realities." ${ }^{\prime 1} \mathrm{He}$ offered a highly abstract "armature on which a more systematic account [of narrative] might be constructed." ${ }^{22}$ This account identified ten features - narrative diachronicity, particularity, intentional state entailments, hermeneutic composability, canonicity and breach, genericness, normativeness, context sensitivity and negotiability, and narrative accrual that, for present purposes, can be condensed to five.

First, narrative consists of "patterns of events occurring over time. ${ }^{83}$ But, Bruner maintained, there are many "conventions for expressing the sequenced durativity of narrative ...." ${ }^{84}$ Second, stories have structural parts - in Vladímir Propp's terms, "functions" that can only be understood relative to the story as a whole, while the story as a whole "is dependent for its formation on the supply of possible constituent parts.... The telling of a story and its comprehension as a story depend on the human capacity to process knowledge in this in-

78. BRUNER, ACTS OF MEANING, supra note 11, at 19.

79. Symposium, Legal Storytelling, 87 MICH. L. REV. 2073 (1989).

80. Winter, Narrative Meaning, supra note 4.

81. Bruner, supra note 21 , at 21.

82. Id. at 5.

83. Id at 6 .

84. Id. 
terpretive way." ${ }^{85}$ Third, stories use the particular to state the general: a "story's components, insofar as they become its 'function' or captives, lose their status as singular and definite referring expressions;" a particular "becomes, as it were, a type rather than a token." ${ }^{86}$ Fourth, though genres channel interpretation for both author and reader, narrative is inherently interpretive. "Interpretation... is studded with problems ... that have to do more with context than text, with the conditions on telling rather than with what is told." 87 For a story to work, the reader must both attribute intentionality to the teller and use her background knowledge to "negotiate" the text. Thus, Bruner explicitly rejected the suspension of disbelief as "at best an idealization of the reader and, at worst, a distortion of what the process of narrative comprehension involves. Inevitably, we assimilate narrative on our own terms ...." $" 88$

Fifth, narrative is "necessarily normative." ${ }^{89}$ Stories "must be about how an implicit canonical script has been breached, violated, or deviated from ...." 90 Trouble "provides the engine of drama" and is "an imbalance between any and all of five elements" of Actor, Goal, Scene, and Instrument. ${ }^{91}$ "The very notion of Trouble presupposes that Actions should fit Goals appropriately, Scenes be suited to Instruments, and so on." ${ }^{2}$ But, "differences in how the notion of breach is conceived" are culturally contingent and resolution of the Trouble is not a necessary element of narrative. ${ }^{93}$

In contrast to this highly abstract, recondite "ground plan," I offered an account of narrative as concrete, highly structured, and systematic. "[N]arrative proceeds from the ground up," deriving its power from its very concreteness. ${ }^{94} \mathrm{I}$ argued that the concept "narrative" could be captured by a single, elegant model structured in terms of four embodied schemas and a handful of basic metaphors. ${ }^{95}$ I then

85. Id. at 8 (discussing Vladimir PropP, MorPhology of the FolkTAle (2d ed. 1968)); see also Jerome Bruner, The Future of Fact: What is Narrative Fact?, 560 ANNALS AM. ACAD. POL. \& SOC. SCI. 17, $22-24$ (1998) (discussing Propp's morphology of narrative).

86. Bruner, supra note 21 , at 13.

87. Id. at 10 .

88. Id. at 17.

89. Id. at 15.

90. Id. at 11.

91. Id. at 16.

92. BRUNER, ACTS OF MEANING, supra note 11 , at 50 .

93. Bruner, supra note 21 , at $15-16$ ("Nor is it required of narrative, by the way, that the Trouble with which it deals be resolved.")

94. Winter, Narrative Meaning, supra note 4, at 2228.

95. Id. at 2239-43. My account of story structure was also drawn from Propp and structuralist successors such as Roland Barthes but owed a great deal to conversations with George Lakoff and Mark Turner. 
showed how that model accounts for a broad range of narrative running all the way from folktales to the avant-garde. ${ }^{96}$

Essentially, that model maps a JOURNEY schema in which the protagonist (the metaphorical or literal traveler) starts in an initial state - a status quo - in which life is in harmonious balance. Something disturbs that balance - a need, a lack, a deprivation, or a transformation. The antagonist is, typically, the agent that causes the transformation or lack. The protagonist sets out to restore the balance; in doing so, he or she encounters obstacles that must be overcome. Typically, the OBSTACLE entailment of the JOURNEY schema is filled out in the story domain with an agon that serves as the pivotal point of the narrative. The agon is an encounter and conflict with the antagonist. Its resolution also restores the initial imbalance or achieves some new balanced state. This provides narrative with a sense of closure. Because a "story is conceptualized as movement along a path ... we do not think it much of a 'story' if the account 'goes nowhere,' if it has no 'point.' "97 Thus, the reader understands the narrator to be asking him or her to follow the story to its end and to draw that point as the moral: "We imagine ourselves as the protagonist and picture ourselves in the protagonist's shoes as we proceed from introduction to conclusion." 98

More elaborate stories are constructed as variants in which the elements of the model are instantiated, reordered, or deliberately deformed in different ways (and to different degrees). Understood as a model that enables such modes of extension, this description of basic story structure accounts for a broad range of narrative running from the Midrash, Aesop's Fables, and Russian folktales, through Apache and other Native American stories all the way to such avant-garde narratives as Samuel Beckett's Waiting for Godot and Tom Stoppard's Rosencrantz and Guildenstern Are Dead. ${ }^{99}$

My purpose in describing an underlying model for the category "narrative" was to argue against then-voguish views that identified narrative as the basic unit that organizes meaning. Thus, my principal point was that we recognize narratives as such because we have a model of basic story structure. This is what enables us immediately to identify the novel, the Midrash, and the Apache historical narrative as examples of the same "thing," as instantiations of the same process. So, too, the meaning of any particular story is only possible because it is constructed of pre-given understandings of common events and con-

96. Id. at 2239-43, 2246-55.

97. Id. at 2236 .

98. Id. at 2272.

99. Id at 2239-55. This argument also appears in my forthcoming book, A CLEARING IN THE FOREST, supra note 36, where I extend the point to include standard legal scholarship such as RONALD DWORKIN, LAW'S EMPIRE (1986). 
cepts, configured into the particular pattern of story-meaning. Like any other form of communication, in other words, narrative is enmeshed in and dependent upon the structures of social meaning commonly referred to as "scripts," "stock stories," or "idealized cognitive models.".

Amsterdam and Bruner now appear to have been persuaded (at least in part) by my basic account of story structure. In their book, they explain that:

Stories go somewhere. They have an end, a telos. If someone drifts in telling a story, we urge him or her to "get to the point." What gives stories this "point" is that, just as they have a telos, they also have to do with some obstacle blocking progress toward it. If there is no obstacle, no Trouble, there is no story - only a recital of some happening that unfolded banally with nothing untoward to tell about. [p. 127]

That basic story trajectory is now captured in what they offer as an "austere definition" of narrative.

The unfolding of the plot requires (implicitly or explicitly):

(1) an initial steady state grounded in the legitimate ordinariness of things,

(2) that gets disrupted by a Trouble consisting of the circumstances attributable to human agency or susceptible to change the human intervention,

(3) in turn evoking efforts at redress or transformation, which succeed or fail,

(4) so that the old steady state is restored or a new (transformed) steady state is created,

(5) and the story concludes by drawing the then-and-there of the tale that has been told into the here-and-now of the telling through some coda say, for example, Aesop's characteristic moral of the story. [pp. 113-14]

Though many of Bruner's original ten features figure in the current account (most notably breach of canonical scripts and the inherently normative quality of narrative (pp. 121-24)), other positions have changed dramatically. ${ }^{100}$ Where previously Bruner maintained that details lose their status as singular and definite, the authors now seem to maintain the opposite, "We convert our telling into some sort of 'higher common sense' by personalizing it, playing on the hearer's identification, giving it a vivid time arrow, and the rest" (p. 135). Where Bruner previously rejected the suspension of disbelief as a

100. Originally, Bruner wrote that: "Insofar as the law insists on such accrual of cases as 'precedents,' and insofar as 'cases' are narratives, the legal system imposes an orderly process of narrative accrual." Bruner, supra note 21 , at 18 . Not surprisingly, the point about precedent has been abandoned. Precedent is now viewed, a la Dworkin, as "like a continuing story, with the links between its continuing episodes forged as much by metaphor and analogy ...." P. 141. 
"distortion of ... the process of narrative comprehension," we are now told that "good narrative leads to the suspension of disbelief and thus serves the ends of rhetoric very well indeed" (p. 135). Most importantly, the idea of Trouble seems to have undergone some unspecified modifications. First, though the former definition of Trouble is repeated (pp. 129-30), Trouble is now also identified with the OBSTACLE entailment of the JOURNEY schema: "Stories go somewhere... If there is no obstacle, no Trouble, there is no story" (p. 127). Second, the claim that Trouble need not be resolved has been left behind and the need for some resolution in the form of a restored or transformed status quo has now been embraced.

But just as Amsterdam and Bruner embrace the new learning on categorization without having fully assimilated its implications, they deploy the model of basic story structure without a thorough understanding of its relation to the fundamental shift in the theory of categorization. Here, as there, something is lost in translation.

First, where I described basic story structure as a model that enables various modes of extension, Amsterdam and Bruner offer it as a definition. ${ }^{101}$ This severely limits the cogency and usefulness of the account. Viewed as a set of criteria, the austere definition plainly cannot begin to account for the range of forms that human storytelling takes. And, as we shall see, this remains true even after Amsterdam and Bruner have grafted onto the austere definition their more elaborate cultural account of narrative. Second, they replicate many of the mistakes catalogued in the previous section. Third, because the authors do not take "narrative" itself as a subject of human processes of categorization, the principal conclusion that they draw is the very one undermined by this approach to story structure (and, more generally, by the approach to categorization they outlined in Chapter Two). And this in turn circumscribes in an important way their reading of Michael $H$.

The authors posit two general theoretical approaches to narrative that they characterize as the "endogenous" (pp. 115-16) and those that involve "culture and human interaction much more directly" (pp. 11617). The central claim of endogenous theories is that "narrative is inherent either in the nature of the human mind, in the nature of language, or in those supposed programs alleged to run our nervous systems" (p. 115). The basic claim of the second group is that "narratives and genres of narrative serve to model characteristic plights of culture sharing human groups" (p. 117). The authors criticize endogenous

101. Cf. Winter, Narrative Meaning, supra note 4, at 2246 (explaining that the model of basic story structure is not "a definition of the categorical, necessary, and sufficient conditions of all stories" but an idealized model "that describes the prototypical story. To put it another way, the model describes the conditions sufficient for an account to be recognizable as a story. It does not purport to define or delimit the necessary conditions for narratives."). 
theories because they leave unspecified the innate mechanism of narrative. "The real issue is what is innate about it, and how it works to constrain the ways we speak" (p. 116). The authors suggest, however, that both endogenous and plight-modeling approaches might be right (p. 119).

The first thing to notice about this way of laying out the issues is that it crudely polarizes the alternatives into the traditional dualism of objective and subjective: either narrative is hard-wired or it is a contingent matter of one's cultural inheritance. The second thing to notice is that, though the authors purport to avoid this crude dichotomization, ${ }^{102}$ in fact they do not. The endogenous dimensions of narrative are never mentioned again. What the reader gets instead is a more detailed version of the plight-modeling, cultural account. Thus, the authors maintain that "forms of life' inherent in a culture's world view" are "embodied and instantiated in its lore and myths. . . . Narrative, in a word, models a culture's conception of human character and its plights" (pp. 131-32). In fact, the authors take the point one step further and claim that "narrative genres are mental models representing possible ways in which events in the human world can go."103

The third thing to notice is that there is already an account of the sort they suggest connecting the embodied (i.e., the endogenous) and the cultural: it is the one summarized earlier. ${ }^{104}$ Amsterdam and Bruner do not discuss it. For one thing, this more complex account is premised on evidence that bodily states - balance, movement through space, blockage, exertion of force to overcome obstacles, etc. - play a constitutive role in higher-order mental functions. ${ }^{105}$ Bruner, no doubt, rejects such theories; for him, the "biological substrate" is at most a precondition for or constraint on action - and one to be overcome by culture, at that ${ }^{106}$ For another, this account is critical of the notion put forward by the authors here that narratives serve, in their words, as "mental models representing possible ways in which events in the human world can go."

102. The authors use this "complementarity" tack again when they say that both the social-institutional positivists and the interpretivists in anthropology are correct. Pp. 225-26.

103. P. 133; cf. Cover, supra note 72 , at 5 ("narratives ... are the trajectories plotted upon material reality by our imaginations").

104. The authors claim that "the extant general theories" do not explain why narrative "depends so fundamentally upon the manipulation of time" pp. 119-20 - though this is a point I thought I had addressed. See Winter, Narrative Meaning, supra note 4, at 2235-38.

105. I detail some of this in my forthcoming book, but a better place to begin is with Gerald Edelman's two most recent books: GERALD M. EDELMAN, BRIGHT AIR, BRILLIANT FIRE: ON THE MATTER OF THE MIND (1992); GERALD M. EDELMAN \& GiUlio TONONI, CONSCIOUSNESS: HOW MATTER BECOMES IMAGINATION (2000).

106. BRUNER, ACTS OF MEANING, supra note 11, at 20-21. Of course, simply ignoring positions with which one disagrees is no substitute for an argument about why one thinks they are wrong. 
The strength of Amsterdam and Bruner's treatment is that it provides a cogent account of the very large class of narratives that weave together a culture's conceptions of what is ordinary and legitimate, of the proper ends of human striving, of the common shapes of misfortune, of the range of possible plights and of the appropriate responses (p. 133). The weakness of their treatment, however, is that it is simultaneously too broad and too narrow. The claim is too broad because not all narratives serve as cultural models. It is hard to shoehorn avant-garde narrative into this definition - though the authors try. ${ }^{107}$ (Surely, Waiting for Godot offers profound commentary on the human condition. But does anyone seriously take it as a mental model for ways in which human life should or shouldn't go?) The claim is too narrow because not all our mental models of how human life should go take the form of narrative. The authors (pp. 45, 121-22), for example, draw a distinction between narratives and scripts such as Schank and Ableson's famous example of the restaurant scenario. ${ }^{108}$ Scripts denote "the normal ways in which people go about and are expected to go about in their ordinary daily lives: how to get a meal in a restaurant, how to plead before a court of law" (p. 121). Narratives "illustrate what happens when a script is thrown off track" (p. 45). But this means, as they seem to recognize, that "much of our background knowledge of the culture is organized in ... scripts" (p. 121). Indeed, without such scripts there would be no narrative at all.

Thus, precisely as I argued in $1989,{ }^{109}$ the problem with accounts that - like Amsterdam and Bruner's - want to ground everything in narrative is that they presuppose the very intersubjectivity they are trying to explain: How do different members of the culture arrive at the same understanding of the meta-narrative? This problem of vicious circularity is clear in Amsterdam and Bruner's account. On one hand, they claim that "[c]ategories are derived or extracted from larger-scale theories, stories, or normative redes about 'reality' ( $p$. 37)." On the other hand, they acknowledge that those same largescale, normative narratives can only be understood by reference to the scripts and categories that organize our background knowledge of the culture. And, after that, it's just turtles all the way down. ${ }^{110}$

107. They suggest (rather lamely, I think) that: "Perhaps Ionesco and Genet launched new possibilities with their creation of the theater of the absurd." P. 133.

108. ROGER C. SCHANK \& ROBERT P. ABELSON, SCRIPTS, PlaNS, GOALS AND UNDERSTANDING: AN INQUIRY INTO HUMAN KNOWLEDGE STRUCTURES $42-46$ (1977), discussed in López, supra note 1, at 5-7 \& nn.5, 8; Winter, Narrative Meaning, supra note 4, at 2233-34.

109. Winter, Narrative Meaning, supra note 4, at 2257-62.

110. See Clifford Geertz, The INTERPREtation of Cultures 28-29 (1973); WILLIAM JAMES, THE WILL TO BELIEVE AND OTHER ESSAYS IN POPULAR PHILOSOPHY 104 (1897) (rocks). 
Of course, not all mental models consist of scripts. Some are image-schematic, some metaphorical, some metonymic. Consider the character that we encountered at the close of the previous section: the statesmanlike judge, the pillar of the community whose duty first and foremost is to the established order. We have neither a script nor a narrative for that; what we have is a mental picture, an image, a role model or iconic representative such as Oliver Wendell Holmes, Jr. ${ }^{111}$ This is the power of Lakoff's concept of an idealized cognitive model: it provides a more general approach to this idea of category structure.

Which brings us to Michael $H$. Following Propp, the authors provide a structural reading of Scalia's plurality opinion as instantiating the adultery-story subspecies of Western combat myths (pp. 79-102). ${ }^{112}$ This reading is followed by a close analysis of the rhetorics of the opinion (pp. 102-09). Both are quite detailed, I have only a quibble or two with these discussions, and I will not try to summarize them. As noted earlier, I think that this is one of the stronger sections of the book.

What interests me, however, is the way in which the focus on narrative and rhetoric obscures a potentially more revealing insight - a deeper unity, as it were - into the worldview that constructs Scalia's text. Consonant with their ingrained view of radical subjectivity, the authors consistently present Scalia in the active voice: "Justice Scalia simultaneously creates the category of 'the unitary family' and sanctifies it" (p. 105). ${ }^{13}$ But it is not a category of family that Scalia is inventing (and, in any event, he would hardly be the first to sanctify it). What Scalia is creating is an unusual label or description - "the unitary family" - for an existing category that already has a conventional name - the nuclear family. ${ }^{114}$ Why, then, the unusual "unitary" label?

111. This, by the way, was Holmes's encomium to Lemuel Shaw: "[T]he strength of that great judge lay in an accurate appreciation of the requirements of the community whose officer he was." Oliver Wendell Holmes, JR., THE COMMON LAW 85 (Mark Howe ed., 1963) (originally published 1881).

112. In one of the better passages, the authors note trenchantly that what "Justice Scalia cannot countenance in Michael $H$. is not that Victoria should have two acknowledged fathers, but rather that Victoria's mother should have two acknowledged lovers: It is this licentious model which cannot be squared with Justice Scalia's cuckold-phobic vision of the "unitary family.' " P. 82. Note the quotes around "unitary family," which is Scalia's phrase.

113. Other examples include:

- "[T]he Demon Lover adultery tale" is "the tale Justice Scalia chooses to tell." P. 99.

- "But Justice Scalia is driving those methodologies while appearing merely to ride them."

P. 106 (emphasis in original).

- "His entire opinion is a demonstration of the limitless license that judges acquire to reify and deify their predilections...." P. 108.

114. Justice Scalia's precise statement is that the right to privacy precedents "rest not upon such isolated factors but upon the historic respect - indeed, sanctity would not be too strong a term - traditionally accorded to the relationships that develop within the unitary family." Michael H. v. Gerald D., 491 U.S. 110, 123 (1989). 
And why invent a new term when, considering his emphasis on tradition, the familiar one would serve Scalia's purposes as well or even better?

Linguistic markings of this sort are significant because they typically indicate some variance from the default assumptions that constitute the standard case. It is of particular interest here because it is so similar to another Scalia coinage - "the unitary executive." That phrase first appears in the United States Reports in Justice Scalia's dissent in Morrison v. Olsen. ${ }^{115}$ It has gained little currency with other members of the Court, ${ }^{116}$ though it has been taken up by some commentators. According to two such proponents, unitary executive theorists read Article II

as creating a hierarchical, unified executive department under the direct control of the President. They conclude that the President alone possesses all of the executive power and that he therefore can direct, control, and supervise inferior officers or agencies who seek to exercise discretionary executive power. ${ }^{117}$

In strikingly similar terms, Justice Scalia describes the parental rights of the father as including

the right to the child's services and earnings; the right to direct the child's activities; the right to make decisions regarding the control, education, and health of the child; and the right, as well as the duty, to prepare the child for additional obligations, which includes the teaching of moral standards, religious beliefs, and elements of good citizenship. ${ }^{118}$

This is what Lakoff has characterized as the "strict father" model underlying political conservatism and conservative morality - a worldview that emphasizes authority, strength, order. ${ }^{119}$ Every family must

115. 487 U.S. 654, 727, 732 (1988) (Scalia, J., dissenting). The position derives from Chief Justice Taft's opinion in Myers v. United States, 272 U.S. 52, 135 (1926) (stating that the President may supervise and guide statutory construction by executive officers "in order to secure that unitary and uniform execution of the laws which Article II of the Constitution evidently contemplated in vesting general executive power in the President alone"); see also United States v. Fausto, 484 U.S. 439, 449 (1988) (Scalia, J.) ("This enables the development ... of a unitary and consistent Executive Branch position on matters involving personnel action ....").

116. The other appearances of the phrase are in Justice Scalia's majority opinion in Printz v. United States, 521 U.S. 898, 923 n.12 (1997), and in a parenthetical in Justice Breyer's dissent in Clinton v. City of New York, 524 U.S. 417, 490 (1998) - an opinion that, incidentally, was joined by Justice Scalia.

117. Steven G. Calabresi \& Kevin H. Rhodes, The Structural Constitution: Unitary Executive, Plural Judiciary, 105 HARV. L. REv. 1155, 1165-66 (1992).

118. 491 U.S. at 118-19 (quoting 4 CALIFORNIA FAMILY LAW $\$ 60.02[1][b]$ (C. Markey ed. 1987)).

119. George Lakoff, Moral Politics: What Conservatives KNow that LIBERALS DON'T 65-67 (1996); see also GEORGE LAKOFF \& MARK JOHNSON, PHILOSOPHY IN THE FLESH: THE EMBODIED MIND AND ITS CHALLENGE TO WESTERN THOUGHT 312-14 (1999). On Justice Scalia's incipient authoritarianism, see Steven L. Winter, What If Justice Scalia Took History and the Rule of Law Seriously?, 12 DUKE ENV'L LAW \& POLICY 
have one father, firmly in control; the country, one president of indisputable and indivisible authority. This worldview, moreover, is of a piece with Justice Scalia's well-known preference for hard-and-fast rules. ${ }^{120}$ Certainly, all this would have come as no surprise to the author of the very first book on law and mind. One can just hear him chuckling in the background, pointing out that

it is obvious enough: To the child the father is the Infallible Judge, the Maker of definite rules of conduct. He knows precisely what is right and what is wrong and, as head of the family, sits in judgment and punishes misdeeds. The Law - a body of rules apparently devised for infallibly determining what is right and what is wrong and for deciding who should be punished for misdeeds - inevitably becomes a partial substitute for the Father-as-Infallible-Judge. That is, the desire persists in grown man to recapture, through a rediscovery of a father, a childish, completely controllable universe, and that desire seeks satisfaction in a partial, unconscious, anthropomorphizing of Law, in ascribing to the Law some of the characteristics of the child's Father-Judge. That childish longing is an important element in the explanation of the absurdly unrealistic notion that Law is, or can be made, entirely certain and definitely predictable. ${ }^{121}$

Indeed, Jerome Frank probably would have said that Justice Scalia longs to be that father. Or, he might have pointed him to the couch.

\section{Misunderstanding LAW AND CULTURE}

There is a virtual revolution going on in the cognitive sciences. Developments over the last three decades have transformed our understanding of categorization, of logic, of imagination, and of the relationship between body and mind. As these developments slowly work their way into legal theory, they will transform the way we see a lot of things. The crude legal realism that focuses on judicial manipulation and its conventional opposite, the search for external constraints, will give way. What will replace them will, I think, be something much closer to the most sophisticated legal realist insights of Karl Llewellyn. For it was Llewellyn who first taught us sixty-five years ago that to categorize is to decide: "[I] f there is the slightest doubt about the classification of the facts - though they be undisputed - the rule cannot decide the case; it is decided by the classifying." 122

Categorization and adjudication are both social processes. Judges must communicate; more than that, they must persuade. They must

FORUM 155 (2001) (Symposium on "Citizen Suits and the Future of Standing in the 21st Century: From Lujan to Laidlaw and Beyond").

120. Antonin Scalia, The Rule of Law as a Law of Rules, 56 U. CHI. L. REV. 1175 (1989).

121. Jerome Frank, LAW AND THE MODERn Mind 18 (1930).

122. Karl N. Llewellyn, The Constitution as an Institution, 34 COLUM. L. REV. 1, 8 (1934). 
persuade us that what they decide is worthy of our obedience, worthy of designation as Law. To do that, their categories must connect with ours in a profound way. That is why judges, even Supreme Court Justices, write like advocates. And that is one of the reasons that culture necessarily works its way into law.

The other reason is both more basic and unavoidable. The fact that categorization is functional and pragmatic means that it is socially contingent in the sense that a society's categories encode its customary operations, its standard repertoire of purposes, its conventional roles, its approved modes of behavior. Categorization, in other words, already does all of the things that Amsterdam and Bruner attribute to narrative. This was already implicit in López's groundbreaking article, and is perhaps its most significant contribution. But once we understand that function and purpose are built-in, constitutive dimensions of our categories, we cannot escape the conclusion that categorization (like narrative) is profoundly normative. With that realization must come the recognition that adjudication is not only intensely political, but also in some sense inherently conservative. For the judge cannot approach the case - any case - without bringing with her the entire repertoire of cultural categories with their normatively loaded understandings. And if the judge is to be persuasive, her categories will have to reflect the most mainstream values and understandings. Which means that adjudication (if not, indeed, law more generally) is typically conservative in the sense that it enforces - and reinforces - the dominant normative views of the culture.

But all that is for another book. 